\title{
Street Businesses in Addis Ababa: Causes, Consequences and Administrative Interventions
}

\author{
Jemal Abagissa \\ College of Business and Economics, \\ Department of Public Administration and Development Management, \\ Addis Ababa University, Ethiopia
}

Corresponding author: jemal.abagissa@aau.edu.et

\begin{abstract}
Street vending has long been a source of debate among development economists. It has been argued that direct government intervention that aids this sector will encourage rural to urban migration. Others have argued that this sector deserves government help as often more than 50\% of the urban labour force is employed by this sector. This study is designed to assess the causes, consequences and administrative interventions of street vending in Addis Ababa with particular reference to Yeka sub-city. Data were collected from randomly selected samples of 330 street vendors, 14 code enforcers and 9 government officials through questionnaires and interview of key respondents. The finding shows most of the traders came from outside Addis Ababa in search of jobs. Street vending proliferated as a way of life and a coping mechanism adopted by those economically under privileged segment of the society. Factors that led to street vending were complex and varied. According to the findings, absence of opportunity in the formal sector was the main factor that led the operators to street vending. This is followed by the need to support their family and themselves. The authorities stated that unless managed well street vending will have negative impact on traffic movement, encroach on public space and create unfair completion with formal businesses. To mitigate these problems the city administration has issued street vending regulation No. 5 in 2018 so that specific vending plots are allocated and the vendors need to do their business legally and those who fail to follow the rules will be dealt with by the law.
\end{abstract}

Keywords: Street Vendors, Causes, Consequences, Code Enforcers, Administrative Interventions

Received: 19/11/2019 Revised: 11/03/2020 Accepted: 13/06/2020 Published: 30/06/2020 


\section{INTRODUCTION}

Despite the advances in modern retailing, millions of people throughout the Third World countries still make their living partly or wholly through selling goods on the streets. This is particularly the case in Africa (Mitullah, 2003). A vibrant array of traders selling anything from fruits and vegetables to clothes, traditional medicine and even furniture is what characterizes African cities.

Youth unemployment and the associated problems of poverty and lack of livelihood opportunities for young people are major causes leading the bulk of new entrants to the urban labour force who create their own employment. Migration and population growth are also causing for the growth of the informal sector in urban areas (Ethiopian Economic Association, 2007). Research on rural youth livelihoods shows that the decrease in farmland in the highlands of Ethiopia coupled with lack of non-farm employment opportunities in the rural areas has pushed youth away from their agricultural livelihoods and rural villages to urban areas (Bezu \& Holden, 2014).

Among the self-employed in the informal sector, street vendors are the most visible in urban areas. In the broader sense, street vendors refer to persons who sell goods in public space as well as those who provide services in public spaces (ILO, 2013b). Many join this sector because informal sector employment is more accessible than formal sector employment to people with low human, financial and social capital.

It has become evident that rapid growth of Addis Ababa is providing both opportunities and risks. One particular aspect emerging as a downside of the growing urbanization process is the proliferation of informal trade, most notably, street vending which has been expanding unabated for the past two decades despite many attempts made by the city government to address the problem.

According to Capital Ethiopia (2018), the exact number of vendors in the city is unknown but a 2014 random study indicated that there were 87,000 street vendors at that time. Now it is estimated that there are over 117,000 vendors working on the street without paying taxes or holding any license. The main objective of the study is to assess the causes, consequences and administrative interventions of street vending in Addis Ababa with particular reference to Yeka sub-city. 


\section{LITERATURE REVIEW}

The concept of informal economy originated in the Third World out of studies on urban labour markets in Africa (Potts, 2007). How to define the informal economy and differentiate it from the formal economy has been an ongoing contest ever since Keith Hart first introduced this concept in his work on Kenya (ILO, 1972) and Ghana (Hart, 1973). The first ILO mission in Kenya distinguished the informal sector from the formal sector on the basis of seven antipodal traits namely easy versus difficult entry; reliance on local rather than foreign resources; family in contrast to corporate ownership; small versus large-scale enterprises; labour intensive and adapted instead of capital intensive and imported technologies; informally rather than formally acquired skills; and unregulated and competitive as opposed to a protected market.

The informal sector comprises of street vendors, domestic workers, homebased workers, construction workers, transport workers, and waste pickers (ILO 2002 b). Street vendors and home-based workers makeup the largest group of informal sector operators. While home-based workers are invisible but numerous, street vendors are the most visible and self-employed entrepreneurs.

Street vending refers to income-generating activities whereby individuals sell their wares along streets and pavements to passing pedestrians and motorists. Cross (1998) uses legal infringements as the defining principle. He terms street vending as the production and exchange of goods and services that involved the lack of appropriate business permits, violation of zoning codes, failure to report tax liability, non-compliance with labour regulations governing contracts, work conditions, and/or legal guarantees in relations with suppliers and clients.

Over the years, there have been continuous debates among the three theories regarding the informal economy. According to the dualist theory, the persistence of informal activities is due to the fact that not enough formal job opportunities have been produced to take in surplus labour due to a slow rate of economic development and a faster rate of urbanization (Tokman 1978). In this logic the economy was conceived as being dual, consisting of traditional and modern sectors. Thus, the dualistic theory views the formal and informal sectors as having almost no links with each other and in theory represents almost two opposite parts of the economy. 
However, (Chen, 2007) disputed the dualist view of thinking by arguing that, the formal and the informal economy are often dynamically linked with many informal enterprises having production or distribution relations with formal enterprises, supplying inputs, goods or services ready for the market either through direct transactions or subcontracting engagements. Moreover, several formal enterprises employ wage workers under informal employment relations, for instance, the majority of part time workers, temporary workers and home workers work for formal enterprises through contracting or subcontracting arrangements.

Hence, in reaction to the dualist theory, a new understanding of the informal sector emerged with the name structuralist. The structuralist theory is also known as the black-market theory, the underground theory, the world systems theory or the Portes theory (Rakowski 1994). The structuralist school was propounded by Moser and by Castells and Portes in the late 1970s and 1980s and they focused on the analysis of the modes of production within the capitalist system and the subordinations that occurred within it (Saha 2009).The structuralist perspective has come to the fore which depicts street vending as a survival practice conducted out of economic necessity as a last resort in the absence of alternative means of livelihood. In this view, such entrepreneurship is a direct by-product of the advent of a de-regulated open world economy. The street vendors are therefore depicted as unwilling and unfortunate pawns in an exploitative global economic system. The sector is highly insecure and unstable, composed of long hours, poor conditions, no legal or social protection, limited access to credit and very limited bargaining power (ILO, 2002a, 2002b; Kapoor, 2007).

The third theory regarding the informal economy is the legalist propounded by Peruvian economist Hernando De Soto (1989) who argued that informality is a consequence of bureaucratic barriers and that the inflexible rules and regulations, terms and conditions for operating a business in the formal sector are so tedious such that it becomes an additional burden for people and hence they are forced to circumvent formal rules and regulations by operating in the informal sector.

Street business is more a matter of choice than due to a lack of choice. For these neo-liberals, such entrepreneurs are heroes throwing off the shackles of a burdensome state and making a rational economic decision to enter street vending to escape over-regulation in the formal realm. As Nwabuzor (2005) asserts, 'informality is a response to burdensome controls, and an attempt to circumvent them. Informal work arrangements are considered as a 
rational response by micro-entrepreneurs to over-regulation by government bureaucracies. This theory is also known as Romantic theory of street vending (De Sato, 1989). This school believes that if the sector is intervened by the government in terms of policies, regulations, capital and skills it could perform in the same way as the formal sector. According to this view, informal firms are potentially productive, but held back by government policies, regulations, and limited access to finance. Therefore, if such barriers would be eliminated informal businesses would register and take advantage of the benefits of their formal status. Generally, this view believes that informal undertakings are similar to official ones.

Despites the debates on the status of street vending, street vending raises the tension between the individual rights to work and the collective rights to public space. In most countries, public space is understood as a collective good that all people have a right to enjoy, and it is the responsibility of local government to regulate its use so that those collective rights can be enjoyed. Opponents of street vendors argue that those collective rights are violated when street vendors appropriate public space for their own use. In this view, as argued, governments must defend public space from such encroachments by strictly regulating or even outlawing street vending.

Hence, street vendors frequently face eviction, arbitrary confiscations of merchandise, demands for bribes, harassment and physical abuse in their work place, including from police and other state actors. State-led evictions that target street vendors are not infrequent and have been justified by city clean-up for modernization; pressure from formal businesses who are worried from 'unfair' competition; and preparation for specific public events such as visits of dignitaries, hosting of international sport competitions and other tourist events (Bromley, 2000; Hansen, 2004; Potts, 2007; Skinner, 2008).

\section{RESEARCH METHODOLOGY}

A descriptive survey design is used to collect data from different sources. Descriptive method is set out to describe and to interpret what is going on. Therefore, the study has been descriptive research with cross sectional data. The primary sources were obtained from interviews and questionnaire filled by respondents to attain the objectives of the study. The study relied on both qualitative and quantitative methods of data collection and analysis. 


\section{Description of the Study Area}

This study is conducted in Addis Ababa, the capital city of the Federal Democratic Republic of Ethiopia. Addis Ababa is also a seat of international organizations such as the African Union (AU) and the United Nations Economic Commission for Africa (UNECA). Consequently, it has become a centre to many people coming from all corners of the country looking for employment opportunities. Hence, with rapid natural population growth and high rate of rural-urban migration, Addis Ababa is one of the fastest growing cites in Africa. This creates critical problems such as unemployment and informality.

For administrative purpose, the city is divided in to ten sub-cities. The subcities are further sub-divided in to whereas (neighbourhoods), which are the third and smallest organizational units in the city. There are 116 whereas in the city administration (City Government of Addis Ababa, 2013).

Table 1.

The Sub-Cities, Their Population Size and Areas in Sq Km

\begin{tabular}{|c|c|c|c|}
\hline No. & Sub-city & Population & Area in Sq. Km \\
\hline & AkakiKaliti & 205,385 & 118.08 \\
\hline & Nifas silk lafto & 358,359 & 68.30 \\
\hline & KolfeKeranio & 485,952 & 61.25 \\
\hline & Gulele & 303,226 & 30.18 \\
\hline & Lideta & 228,547 & 9.18 \\
\hline & Kirkos & 250,665 & 14.62 \\
\hline & Arada & 239,638 & 9.91 \\
\hline & Addis ketema & 289,344 & 7.41 \\
\hline & Yeka & 392,781 & 85.98 \\
\hline & Bole & 350,102 & 122.08 \\
\hline
\end{tabular}

Source: 2013 CSA projection

The focus of this study is Yeka sub-city. Yeka is located in the northeast part of Addis Ababa. The particular locality is called Megenagna where the survey took place. 


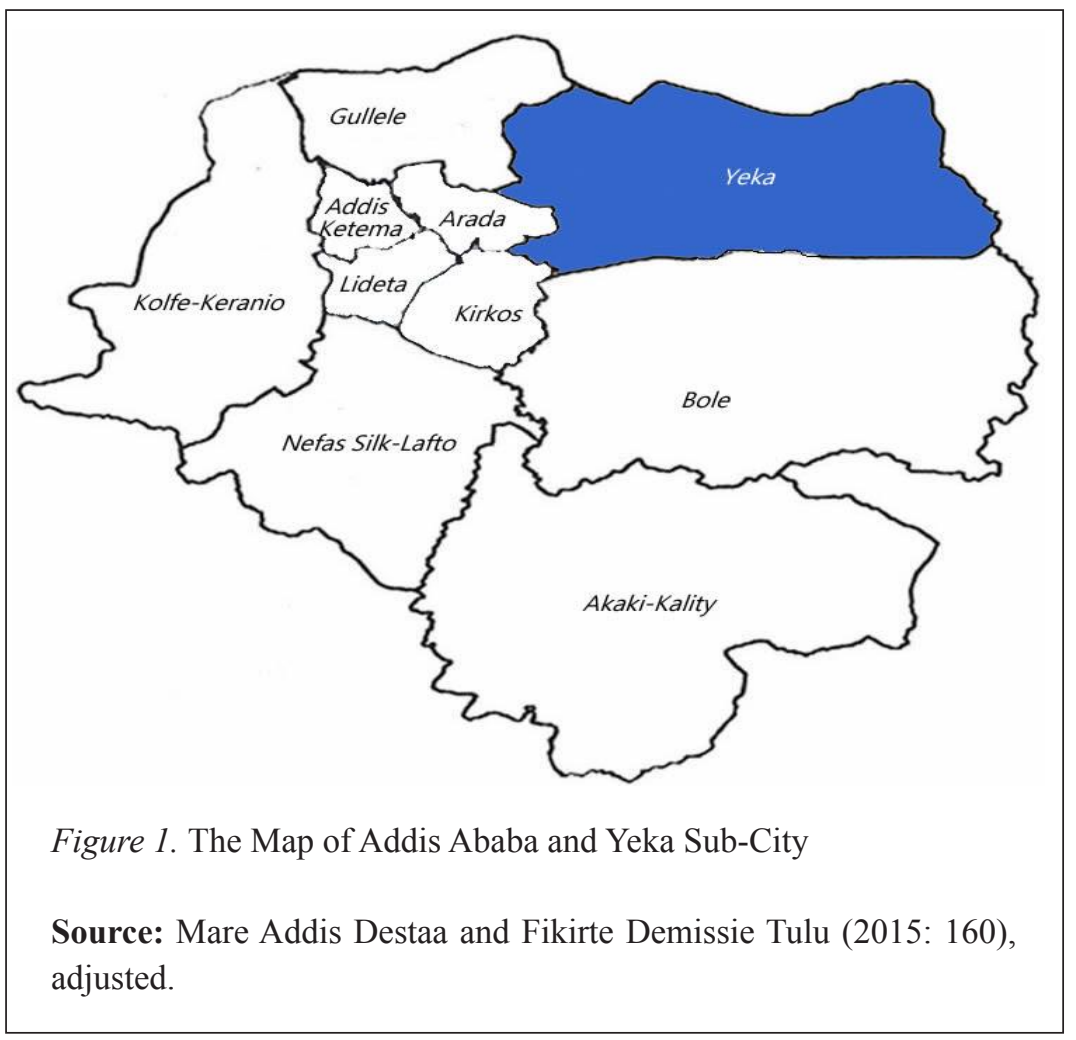

\section{Sources of Data}

The study employed mainly primary data. The primary sources of data were collected from street vendors, code enforcers and sub-city officials. These primary data were collected through questionnaires and interviews. The questionnaires comprised both closed and open-ended questions.

Key informant interviews were used to collect data from the Yeka sub-city Trade and Industry Office Street Vendors Monitoring, Support Case team and from Code Enforcers. The secondary data have been collected from various online and offline reports published by various institutions and agencies. 
Table 2.

Target Population

\begin{tabular}{|c|l|c|c|}
\hline No. & Respondents & Study Area & Target Population \\
\hline 1 & Street vendors & Megenagna & 1923 \\
\hline 2 & Security guard & $\begin{array}{c}\text { Yeka sub-city security Guard } \\
\text { office }\end{array}$ & 15 \\
\hline 3 & $\begin{array}{c}\text { Government } \\
\text { officials }\end{array}$ & $\begin{array}{c}\text { Yeka sub-city Trade and } \\
\text { Industry Office Street } \\
\text { Vendors Monitoring, support } \\
\text { and transition Case team }\end{array}$ & 1947 \\
\hline
\end{tabular}

Source: Yeka sub-city street vendors monitoring and administration team.

\section{Sample Size}

The basis for determining the sample size in each option is the level of precision or sampling error, the confidence level and the degree of variability in the attributes being measured. The ample size of the study is determined by using a simplified formula provided by Yamane (1967) with a consideration of the $95 \%$ confidence level and 0.05 of the margin of error.

$\mathrm{n}=\frac{N}{1+N(e)^{2}}$

Where:

$\mathrm{N}=$ Population Size

$\mathrm{n}=$ Sample Size

$\mathrm{e}=$ Precision (Sampling Error).

Accordingly, 330 respondents were selected from the 1923 street vendors from Megenegna Site, and also 9 respondents were selected from a total of 9 government officials and 14 respondents from a total population of 15 Code enforcers. 
Table 3 .

Target Population and Sample Size

\begin{tabular}{|l|l|l|l|l|}
\hline No. & $\begin{array}{l}\text { Target Population } \\
\text { (Responsible body) }\end{array}$ & Study Area & $\begin{array}{l}\text { Target } \\
\text { Population }\end{array}$ & $\begin{array}{l}\text { Sample } \\
\text { Size }\end{array}$ \\
\hline 1 & Street vendors & Megenagna & 1923 & 330 \\
\hline 2 & Code enforcers & $\begin{array}{l}\text { Yeka sub-city Code } \\
\text { enforcers }\end{array}$ & 15 & 14 \\
\hline 3 & $\begin{array}{l}\text { Government } \\
\text { officials }\end{array}$ & $\begin{array}{l}\text { Yeka sub-city Trade } \\
\text { and Industry Office } \\
\text { Street Vendors } \\
\text { Monitoring, support } \\
\text { and transition Case } \\
\text { team }\end{array}$ & 9 & 9 \\
\hline & Total & 353 \\
\hline
\end{tabular}

Source: Own data (2019)

\section{DATA ANALYSIS AND DISCUSSION}

This part presented the back ground of street vendors, the reasons why they are engaged in street vending business the sources of goods sold by street vendors, the challenges encountered and related issues.

\section{Street Vendors Background}

One particular aspect emerging as a downside of the growing urbanization process is the proliferation of informal trade, most notably, street vending which has been expanding unabated for the past two decades despite many attempts made by the city government to address the problem. 


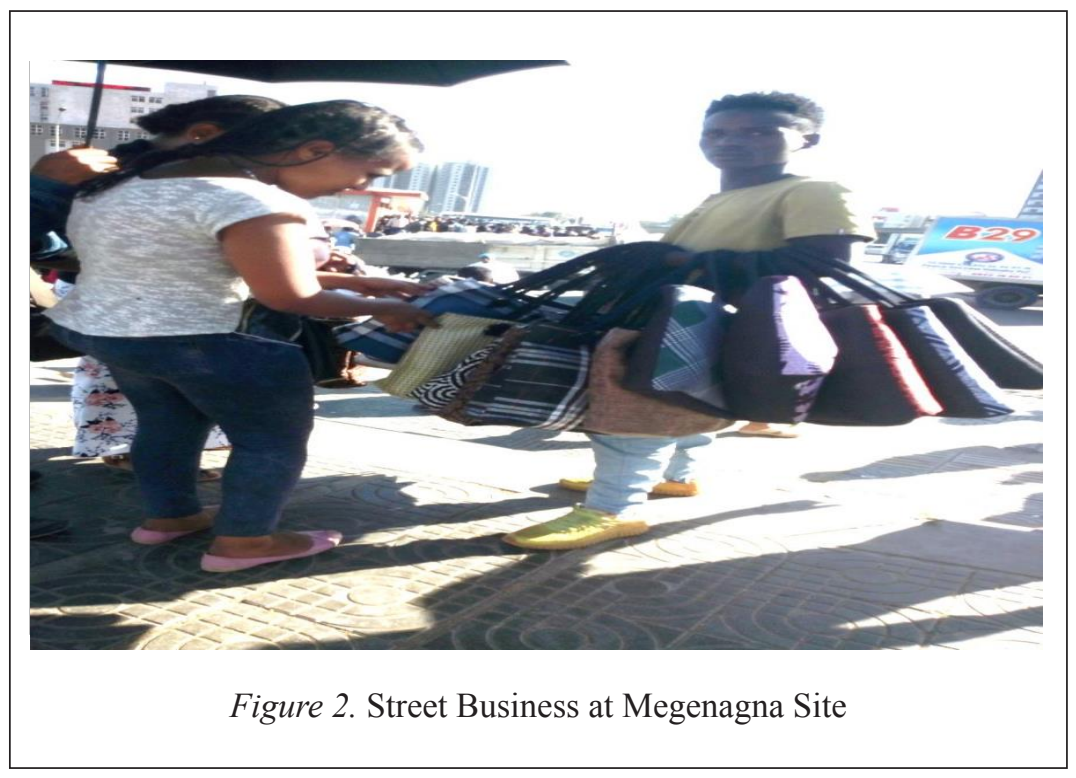

\section{Profile of Respondents}

In this section various primary data were analysed including sociodemographic aspects of the respondents.

\section{Place of Birth}

As table 4 indicated that the birth place of those engaged in the street business is predominantly outside Addis Ababa. In this sample, 297 (90\%) are migrants coming from regions and only 33(10\%) are from Addis Ababa.

Table 4.

Place of Birth of Respondents

\begin{tabular}{llll}
\hline No & Place of Birth of Respondents & Frequency & Percent \\
\hline 1 & Addis Ababa & 33 & 10.0 \\
2 & $\begin{array}{l}\text { Regional Cities and Rural } \\
\text { areas }\end{array}$ & 297 & 90.0 \\
\multicolumn{2}{l}{ Total } & 330 & 100.0 \\
\hline
\end{tabular}

Source: Field survey (2019) 


\section{Ages of Respondents}

The data showed that from 330 respondents 16(4.8\%) were between12-17 years old and $290(87.9 \%)$ were between 18-29 years old, 20(6.1\%) were adults whose age ranges between (30-40 year) and finally 4(1.2\%) were 41 years old and above.

Table 5 .

Age of Respondents

\begin{tabular}{cccc}
\hline No. & Age of Respondents & Frequency & Percentage \\
\hline 1 & $12-17$ & 16 & 4.8 \\
2 & $18-29$ & 290 & 87.9 \\
3 & $30-40$ & 20 & 6.1 \\
4 & 41 and above & 4 & 1.2 \\
& Total & 330 & 100.0 \\
\hline
\end{tabular}

Source: Field survey (2019)

More than $92 \%$ of the individuals surveyed are in the age group 12-29 and the oldest age observed is $1.2 \%$. The data shows most of the respondents are in active age group to operate this business. The data also imply that it is difficult for code enforcers to control street vendors by using physical power.

\section{Sex of the Respondents}

The result shows that one third of respondents $(33.3 \%)$ were female, whereas the majority $(66.7 \%)$ were male operators. 
Table 6.

Sex of Respondents

\begin{tabular}{ccc}
\hline Sex & Frequency & Percentage \\
\hline Male & 220 & 66.7 \\
Female & 110 & 33.3 \\
Total & 330 & 100 \\
\hline
\end{tabular}

Source: Field survey (2019)

\section{Previous Occupation of the Respondents}

The status of respondents' previous employment situation can impact their current work status. As shown in the table below, 23(7.0\%) were previously engaged in formal businesses, $258(78.2 \%)$ were students, 3(0.9\%) were farmers and 46(13.9\%) were daily laborer's. Students dominated the street vendors' population implying that more students in a rural area are quitting their education due to poverty.

Table 7.

Previous Occupations

\begin{tabular}{cccc}
\hline No & Variables & Frequency & Percentage \\
\hline 1.1 & Formal businesses & 23 & 7.0 \\
1.2 & Students & 258 & 78.2 \\
1.3 & Farmers & 3 & 0.9 \\
1.4 & Daily laborer's & 46 & 13.9 \\
& Total & 330 & 100.0 \\
\hline
\end{tabular}

Source: Field survey (2019)

\section{Parents'Occupation of Respondents}

Parents or guardian's occupation has also its impact on the decisions of the vendors current employment and status. In this regard 66 (20\%) responded that their parents were merchants, 12 (3.6\%) government employees, 
242(73.3\%) were farmers, and 10(3\%) were self-employed. Most parents were farmers implying the main causes of youth migration is low productivity in agriculture in rural Ethiopia.

Table 8 .

Parents' Occupation of Street Vendors

\begin{tabular}{lll}
\hline Street Vendors Parents' Occupation & Frequency & Percentage \\
\hline Merchants & 66 & 20.0 \\
Government employees & 12 & 3.6 \\
Farmers & 242 & 73.3 \\
Self-employed & 10 & 3.0 \\
Total & 330 & 100.0 \\
\hline
\end{tabular}

Source: Field survey (2019)

\section{The Main Causes That Forced Young People to Be Street Vendors}

Engagement in street vending is a consequence of multiple factors. Table 9 shows that the majority of respondents involved in street business due to the lack of supporter, which is $49.7 \%$; whereas $25.8 \%$ are due to lack of opportunity to join the formal sector.

Table 9.

Reasons That Forced to Be Street Vendor

\begin{tabular}{|c|c|c|}
\hline $\begin{array}{l}\text { What are the main reasons that forced as } \\
\text { you to be a street vendor? }\end{array}$ & Frequency & Percentage \\
\hline To support family & 73 & 22.1 \\
\hline Due to lack of income & 164 & 49.7 \\
\hline $\begin{array}{l}\text { Inadequate previous employment } \\
\text { conditions }\end{array}$ & 8 & 2.4 \\
\hline Lack of opportunity to join formal job & 85 & 25.8 \\
\hline Total & 330 & 100.0 \\
\hline
\end{tabular}

Source: Field survey (2019). 
There were a number of factors that compel people to embark on street vending business. Some of these factors include the fact that vending is the easiest and fastest means to earn income; vending acts a way of livelihood for the poor families; inadequate jobs in the formal sector; fewer obstacles to start a vending venture; lack of capital to start formal business; working hours are very flexible compared to the formal sector; vending business is not associated with costs that consumes profits such as overhead costs such as licensing fees, rates, and rentals.

\section{Profitability of Street Vending Business}

The vendors said that street vending business is profitable because vendors do not pay tax and vending place rent. Moreover, the market condition is dynamic as vendors frequently change their places to find areas where most customers are accessible.

Table 10.

The Profitability of Street Vending Business

\begin{tabular}{lcc}
\hline Is your business profitable? & Frequency & Percentage \\
\hline Yes & 236 & 71.5 \\
No & 94 & 28.5 \\
Total & 330 & 100.0 \\
\hline
\end{tabular}

Source: Field survey (2019)

There were $236(71.5 \%)$ respondents who said that street vending business was profitable and only $94(28.5 \%)$ of them answered the business is not profitable. The income of street vendors depends on the products they sell, and it varies from product to product, from location to location, and in terms of the volume of trade. Interestingly the incomes of vendors selling garments and electronics items differ from those of vegetable vendors because there was high demand for these goods.

However, the disadvantage of street vending business is lack of shade that causes damages to goods due to exposure to sunlight and rain and certainly also threat of confiscation.

Local authorities, namely, the police and code enforcers try to prevent street vendors from using places for their trade. Their market is often perceived in 
terms of 'encroachments upon public space' leading to overcrowding, traffic jams and road accidents.

\section{The Kinds of Goods Which Are Sold By Street Vendors}

A range of goods are sold on the streets of Addis Ababa including but not limited to roasted grain, peanut, vegetables, fruits, clothes, socks, pairs of shoes electric equipment, bugs cosmetics, perfume, lotion and cream, household appliances, cigarettes, wallets, chewing gums, candy, mobile cards, toilets tissues, belts , umbrellas, soaps, watches, bandeau, barrette, hair grip, comb and brush, toy and books.

Table 11 .

List of Goods Sold By Street Vendors

\begin{tabular}{lcc}
\hline Kind of goods sold & Frequency & Percentage \\
\hline Roasted Grain and Peanut & 39 & 11.8 \\
Vegetables, fruits, ingredient & 28 & 8.5 \\
Clothes and socks & 81 & 24.5 \\
Shoes & 32 & 9.7 \\
electrical equipment's & 19 & 5.8 \\
Bugs & 17 & 5.2 \\
Cosmetics, perfume, lotion and face-Cream & 4 & 1.2 \\
Equipment's used for household purpose & 12 & 3.6 \\
Cigarettes, wallet chewing gum, Candy, & 33 & 10.0 \\
mobile cards, tissues, etc. & 6 & 1.8 \\
Belts & 10 & 3.0 \\
Umbrellas & 11 & 3.3 \\
Soaps & 13 & 3.9 \\
Watches & 14 & 4.2 \\
Bandeau, barrette, hair grip, comb, brush, etc & 10 & 3.0 \\
Toy & 1 & .3 \\
Book & 330 & 100.0 \\
Total & &
\end{tabular}

Source: Field survey (2019) 


\section{The Origin of Street Goods}

One of the issues that the residents of Addis Ababa wonder is from where such variety of goods come. The data shows that $99 \%$ of respondents have bought goods from formal business owners who operate their business in Merkato and Kolfe areas of the City. Only 0.6 and $0.3 \%$ buy their goods from producers and contraband respectively.

Table 12.

The Sources of Street Goods

\begin{tabular}{lcc}
\hline Sources of Goods & Frequency & Percent \\
\hline formal traders & 327 & 99.1 \\
Producers & 2 & .6 \\
Contrabandists & 1 & .3 \\
Total & 330 & 100.0 \\
\hline
\end{tabular}

Source: Field survey (2019)

\section{Other Income Sources of Street Vendors}

As shown in the table below $98.8 \%$ of the respondents have no another sources of income; only $1.2 \%$ of them operate alternative activities such as casual jobs, daily labour and assistance from relatives. Most of the respondents are full time vendors with no other sources of income.

Table 13.

Street Vendors' Alternative Income Sources

\begin{tabular}{clcc}
\hline No & Did You Have Another Source Of Income? & Frequency & Percentage \\
\hline 1 & Yes & 4 & 1.2 \\
2 & No & 326 & 98.8 \\
3 & Total & 330 & 100.0 \\
& If "Yes" What Is The Source Of Income? & Frequency & Percentage \\
1 & Casual & 1 & .3 \\
2 & Daily labour & 1 & .3 \\
3 & Assistance from relatives & 1 & .3 \\
4 & No another source of income & 327 & 99.1 \\
& Total & 330 & 100.0 \\
\hline
\end{tabular}

Source: Field survey (2019) 


\section{Problems Street Vending Creates To The Residents}

Street vending is illegal activity in Ethiopian trade law and regulation. For this reason, law enforcers have taken actions. The venders occupy the footpath leaving no space to the pedestrians. This has become a public concern because it creates problem for vehicular and pedestrian's movement and pollutes the environment. Many people have no positive image about street vendors and pedestrians are annoyed by their encroachment of sidewalks. At some places it is difficult to walk straight. People then will have to pass the narrow aisles between seller stalls walking sideways. When the sidewalks are too crowded people are forced to step onto the road to walk which is a very dangerous exercise. Drivers and other road users also dislike them for their road encroachment. The table below shows a list of these problems.

Table 14.

Problems Caused By Of Street Vendors

\begin{tabular}{lcc}
\hline Problems & Frequency & Percentage \\
\hline Causes car accident and traffic jam & 32 & 25 \\
Affects formal business & 40 & 32 \\
Expose the pedestrians to traffic accidents & 15 & 12.1 \\
Pollutes environment & 5 & 4.0 \\
Affects customers' health due to shoddy goods & 8 & 6.5 \\
Affects City beauty & 4 & 3.2 \\
Affects government revenue & 8 & 6.5 \\
Encourages illegality & 12 & 9.7 \\
Total & 124 & 100.0 \\
\hline
\end{tabular}

Source: Field survey (2019)

\section{Code Enforcers}

Code enforcers are the main government body which control and manage the street vending. The main duties and responsibilities of this government body is awareness creation to street venders about the rules and regulations of formal trade, confiscating goods from street vendors and depositing the same in government stores which is to be sold later based on government financial rules and regulations. 
The officials highlighted that vendors are involved in unorthodox means that violate modern urban management practices. Vendors create multiple challenges such as blocking of pavements, cause littering of the streets, they sell unhygienic food and shoddy merchandise whose source is unknown, and disrupt free movement of vehicular traffic.

In line with this, mainstream critics of street vending argued that street vendors are a negative force in cities. Some argue that tolerating street vendors is costly because street vendors contribute to vehicular congestion and pollution by crowding busy thoroughfares and slowing traffic.

\section{Efforts Made by the City Government to Mitigate the Problem}

Critics of street vending argued that vendors compete unfairly against formal market because they do not incur registration and taxation costs, and do not have costs such as rent and utility payments. This creates unfair competition; the argument goes, threatening the viability of off-street establishments. Following this reasoning, local governments attempt to "formalize" street vendors by relocating them to off-street premises where they would be expected to register, pay taxes and rent or own their workplace.

In Addis Ababa, efforts have been made to address street vending by way of providing small vending shops and allowing Sunday street markets though it had little to contribute to minimizing the problem. Street vending has rather expanded in volume and continued as irritation for the city residents and a threat to legal traders. In the context of Addis Ababa, it has proliferated as a way of life and a coping mechanism adopted by those economically under privileged segments of the society. It is also considered as the chief source of self-employment for the unskilled labour. This prompted the City Administration to take positive action than continuous punitive measures. Hence it has recently issued street business monitoring regulation.

\section{Regulation No. 5/2018}

Recognizing the magnitude of the street vending in the City, the City Administration issued Regulation No, 5, 2018. The regulation states that street business should be regularized and operate from designated places only. The City's MSE (micro and small enterprisers) and Addis Ababa Trade Bureau are mandated to regulate and manage the sector. For instance MSE's roles and mandates are identified as: 
- Create awareness, organize them as business entity and assist them to become formal

- $\quad$ Provide training and advice

- Help them save part of their earnings

- Facilitate credit provision

Moreover, the Addis Ababa Trade Bureau had a street trade policy approved by the city council and identified 45 potential locations for street vendors to conduct business legally. These places are selected because they are supposed to have low traffic congestion, asphalt roads, and open spaces. When these designated street vending locations opened up, vendors will be allowed to sell small electronic items like watches, mobiles and sockets, they also will be able to sell electric wires, tape recorders, and beverages like packed juices and soft drinks. There will also be places to sell clothing and street foods like biscuits, chips, sweets, candies and snack foods. Accordingly, 35,000 street vendors are already registered with the administration including the 7500 vendors who are given plots of land in 2018.

Some places will be open Monday through Sunday as long as it does not affect traffic. If traffic congestion occurs, the Bureau will limit the vending to nights and weekends. The vendors working on the street must have a license. They need to have a permit card displayed visibly that bears legal stamp. That card will state their name, type of business they are conducting and the area they are allowed to operate. If they operate without this permit, they will face legal action including having what they are selling confiscated and possible imprisonment.

The Trade Bureau has established a department that handles street trading in the city and it is currently hiring staff to run its job. The street trade monitoring department will have more than 2,000 staff. Some will work in the central office while others will work in the Woredas (neighbourhoods). The Bureau will also work with relevant city offices such as Transport Bureau, Customs Authority, Roads Authority, Police Commission, Traffic Department, Urban Beatification and Parks bureaus to properly manage street vendors.

Countries like Indonesia and Thailand used similar approaches in more patterned way to deal with the rising population of street vendors in many cities of their countries. According to Caroline Paskarina, Rina Hermawati, et. al (2017), approaches employed in those cities include regularizing business vendors and bringing their activities within the scope of city authorization, 
for example by designating some pavement areas to accommodate street vending businesses, reduce the number of street vendors in temporary areas and outside designated areas. For example, in Bangkok there are at least four models of street vendors' regulators, namely: zone systems, i.e. certain areas allocated to street vendors, trading time systems, such as weekend and night markets, mall or centre integration shopping, and giving street vendors in pedestrian, parks and sidewalks, with certain conditions.

Bandung City Government issued a special regulation on street vendors known as Local Regulation No. 4 of 2011 on the Development and Regulation of Street Vendors that largely contain spatial street vendors, implementing organizations, limiting the number of street vendors and consumer behaviour approach. The city regulates the street vendors using zoning system and applies fines for buyers in red and yellow zones. The division of selling locations of street vendors consisting of 3 zones, namely red zone (location must not be street vendors), yellow zone (locations that can be opened and closed based on time and place) and green zone (location allowed to trade for street vendors).

\section{CONCLUSION}

This study is designed to assess the causes, consequences and administrative interventions of street vending in Addis Ababa with particular reference to Yeka sub-city. The study employed mainly primary data. The primary sources of data were collected from street vendors and city officials. The study revealed that the majority of the study participants are in the productive age category who came mostly from outside Addis Ababa from rural regions of the country in search of job opportunities. Street vending proliferated as a way of life and a coping mechanism adopted by those economically under privileged segment of the society.

Factors that led street vending activities were complex and varied. According to the findings, absence of opportunity for formal job was the main factor that led them to street vending. Lack of gainful employment coupled with poverty in rural areas pushed young people out of their villages in search of a better existence in the city. These migrants do not possess the skills or the education to enable them to find better-paid, secure employment in the formal sector. It has become a public concern that street vending creates problem for vehicular and pedestrian's movement, and has polluted the environment by 
littering the streets. They occupy public places and roads, which can also create social problems like pick pocketing, crime and theft.

In the context of City Administration largely used punitive measures to control street vending. However, coercive measures have rarely been sustainable solutions beyond the immediate short term. Where coercive measures are used as a stand-alone policy, they are unlikely to succeed in getting vendors off the street. This explains why so many times resilient street vendors have soon returned to the streets in Addis Ababa after evictions. When asked how successful the use of force has been, most of the key informants acknowledged that the use of force has not proved any positive result as the vendors kept returning to the streets.

With this in mind, City Administration has issued a regulation (Regulation No.5/2018) to manage the sector. Efforts have been made to address street vending by way of providing small vending shops and allowing Sunday street markets. The Addis Ababa Trade and Industry Bureau is mandated to implement the regulation. The Bureau created open spaces that are far from traffic congestion and Sunday Market areas to accommodate street vendors and those residents who depend on these markets.

The use of vending permits and license systems is believed to exert some control over access to urban public space. Besides revenue generation, this regulatory device also enables the City Administration to prevent congestion and related environmental problems. This strategy is aimed at graduating street vendors into formal jobs according to their capabilities. The strategy entails categorizing the vendors according to their trading specification in merchandise and offering training in the vendors' areas of interest for them to expand their entrepreneurial potentials through micro and small enterprises.

However, the challenge is that not all vendors will graduate because many of them joined the sector for survival. Street vendors are categorized as survivalists' entrepreneurs with very little growth oriented. Survivalist vendors do not start their business by choice. The majority of survivalist vendors do not pursue expansion in their business rather they are necessity driven entrepreneurs that are forced into selling due to joblessness or other economic shocks.

The other problem is finding locations that are suitable for street vendors. The location offered by the government is generally rejected by street vendors 
due to the lack of access to the location; the lack of consumers in location, location is not in accordance with the majority of commodities traded and so forth.

The researcher believes that the effort of the City Administration alone cannot solve the problem as the major cause of increased street vendor population is due to rural labor migration caused by rural poverty. Rural development is very important to prevent rural labor migrating to urban areas. With prosperity in the villages, there will be less need to search for employment in the already crowded cities.

\section{REFERENCES}

Bezu and Holden. (2014). Street based self-employment: A poverty trap or a stepping stone for migrant youth in Africa? School of Economics and Business, Norwegian University of Life Sciences

Bromley, R. (2000). Street Vending and Public Policy: A Global Review. The International Journal of Sociology and Social Policy, 20(1/2),1-28.

Caroline P., Rina H. (2017). Patterns of Power Relations in Governing Street Vendors. A Case Study of Bandung, Indonesia. Advances in Economics, Business and Management Research (AEBMR), volume 43International Conference on Administrative Science (ICAS 2017).

Charmes, J. (2000). Informal Sector, Poverty and Gender: A Review of Empirical Evidence. Paper commissioned for World Development Report 2000/1. Washington D.C: World Bank.

Cross, J. C. (1998). Informal Politics: Street Vendors and The State in Mexico City. Stanford University Press, California.

Chen, M. (2007). Rethinking the informal economy; Linkages with the formal economy and the formal regulatory environment. United Nations University, world institute of development Economics Research. Retrieved from http;/www.un.org/esa/desa/paper.

De Soto, H. (1989), The Other Path: The Invisible Revolution in the Third World, Harper and Row, New York.

Ethiopian Economic Association. (2007). Report on the Ethiopian Economy: Unemployment Challenges and Prospects, Ethiopian Economic Association, Addis Ababa.

Hart, K. (1973). Informal Income Opportunities And Urban Employment in Ghana. The Journal of Modern African Studies, 11(01),61-89.

Hansen, K. T. (2004). Who Rules the Streets? The Politics of Vending Space. Lusaka', Reconsidering Informality: Perspectives From Urban Africa, 62-80. 
International Labor Office (ILO). (1972). Employment, incomes and equality: a strategy for increasing productive employment in Kenya. Report of an inter-agency team financed by the United Nation Development Program and Organized by the International Labor Office. Retrieved from http://www.ilo.org/public/libdoc/ilo/1972/72B09_608_engl.pdf International Labor Office (ILO). (2002), Women and Men in the Informal Economy: A Statistical Picture, International Labour Office, Geneva. International Labor Office (ILO). (2013b). Women and men in the informal economy: a statistical picture (second edition), International Labour Office, Geneva.

International Labour Office (ILO). (2013a). Global Employment Trends for Youth 2013: A generation at risk . International Labour Office, Geneva.

John, C. (2000), Street Vendors, Modernity and Post Modernity: Conflict and Compromise in the Global Economy.

Mare Addis Destaab and FikirteDemissie Tulu. (2015), Mapping of Plantation Forest in the Upper Catchment of Addis Ababa, International Journal of Environmental Sciences, 4(3)158-165

Mitullah, W.V. (2003). Street Vending in African Cities: Synthesis of Empirical Findings from Kenya, Cote d'Ivoire, Ghana, Zimbabwe, Uganda and South Africa, Washington

Moser, C., N. (1978). Informal Sector or Petty Commodity Production: Dualism or Independence in Urban Development?, World Development, 6, 9-10.

Potts, D. (2007). City life in Zimbabwe at a time of fear and loathing: urban planning, urban poverty, and Operation Murambatsvina. In M. J. Murray \& G. A. Myers (Eds.), Cities in contemporary Africa (pp. 265288): Macmillan.

Rakowski, C.A. (1994). Convergence and Divergence in the Informal Sector Debate: A Focus on Latin America, 1984-92. World Development 22(4),501-516.

Sabine, B. (2002). Informal Employment in Countries in Transition: A Conceptual Framework. Available at SSRN: https://ssrn.com/ abstract $=1158947$

Saha, D. (2009). Decent Work for the Street Vendors in Mumbai, India-A Distant Vision. Journal of Workplace Rights, 14(2), 229-250.

Skinner, C. (2008). Street trade in Africa: A review: School of Development Studies, University of Kwazulu-Natal.

Tesfaye Getnet (2018), City Designates 45 Street Vending Areas, Capital Ethiopia Newspaper, Available at .www.capitalethiopia.com

Victor E. T (1978). An Exploration Into The Nature Of Informal--Formal Sector Relationships, World Development, 6(9-10), 1065-1075. 
